JOURNAL OF SECURITY AND SUSTAINABILITY ISSUES ISSN 2029-7017 print/ISSN 2029-7025 online

2019 December Volume 9 Number 2

http://doi.org/10.9770/jssi.2019.9.2(7)

Scopus

\title{
DEVELOPMENT OF CREATIVE CLUSTERS OF A POLICULTURAL REGION: CHALLENGES FOR GOVERNANCE
}

\author{
Yelena Petrenko ${ }^{1}$ Elena Vechkinzova ${ }^{2}$, Lyussiya Togaibayeva ${ }^{3}$ \\ ${ }^{1}$ LLP "Rational solutions", 100000, Karaganda, Microdistrict Orbita-1 11/1, Kazakhstan \\ ${ }^{1}$ Plekhanov Russian University of Economic, 117997, Moscow, Stremyanny lane 36, Russia \\ ${ }^{2}$ Karaganda University "Bolashak", 100018, Karaganda, Yerubaev St., 16, Kazakhstan \\ ${ }^{3}$ Karaganda State Technical University, 100000, Karaganda, Nursultan Nazarbayev St., 56, Kazakhstan \\ E-mails: ${ }^{1}$ petrenko_yelena@bk.ru; ${ }^{2 k v i n 07 @ l i s t . r u,{ }^{3} t o g l u s i a @ m a i l . r u}$
}

Received 11 January 2019; accepted 10 September 2019; published 15 December 2019

\begin{abstract}
In the current conditions of global competition, various regions are struggling to attract investment and human resources. The most successful are creative clusters in which a new product with increased consumer value is created. However, for the formation of creative clusters it is necessary to provide a number of conditions: tolerance, talents, technology. Tolerance implies the presence of specialists with different competencies and behaviors. A decrease in the tolerance coefficient leads not only to a risk of low susceptibility of cultural indigents from other countries, but also to a decrease in the variety of forms and ways of thinking, creative realization, selfexpression, which directly affects the country's innovative and economic development.By the example of assessing the potential of creative clusters in Kazakhstan, it is shown that the loss of tolerance leads to a risk of a decrease in creative potential. The calculation of mathematical clustering was carried out in the STATISTICA program. The state should ensure multicultural diversity for the conditions of innovative development. By an example of assessing the potential of creative clusters in Kazakhstan, it is shown that the loss of tolerance leads to a risk of a decrease in creative potential. The state should ensure multicultural diversity for the conditions of innovative development. a decrease in tolerance directly reduces the potential for the formation of creative spaces, and is also an indicator of the risk of monocultural development, the lag of Kazakhstan in the educational, scientific and innovative spheres of the international country community.
\end{abstract}

Keywords: creative spaces; creative cluster; multicultural environment; mathematical clustering

Reference to this paper should be made as follows: Petrenko, Y., Vechkinzova, E., Togaibayeva, L. 2019. Development of creative clusters of a policultural region: challenges for governance, Journal of Security and Sustainability Issues 9(2): 447-456.

http://doi.org/10.9770/jssi.2019.9.2(7)

JEL Classifications: C01, C82, M00, M20, O18, O53; P4; P47

\section{Introduction}

In the context of the globalization of economic and social life, multicultural regions are becoming territories of particular growth. It is in regions with multicultural characteristics that creative spaces are emerging, and creative clusters may arise. Creative spaces are actively emerging in various regions, including their development in the countries of the post-Soviet space. However, the successful practice of managing such entities has not yet been formed; many regions assess their inherent multiculturalism as a risk factor for interethnic conflicts and do not see creative potential. The issue of maintaining multiculturalism or leveling it in Central Asian countries, including Kazakhstan, is particularly acute. The study of the laws governing the formation of creative spaces and the development of a methodology for managing them becomes the task of the region's economic development, preservation of political stability and the realization of human resources in a creative social environment. The relevance of the study is due to the novelty of the object in question, its complex nature and great potential for the development of the region. 


\section{Theoretical background}

The definition of creative spaces is actively used in the media space, since such sites have become integral centers of cultural life in large cities. However, in the scientific literature, the discussion about the content of the concept of "creative space" is still ongoing. The study of creative spaces and creative clusters is the work of Florida R. (2002), Montgomery, J. (2005), Markusen A. (2006) Hoyman M. and Faricy C. (2009), Rindermann H., Sailer M. and Thompson J. (2009), Rindermann H. and Thompson J. (2011), Sukhovskaya D. (2013, 2015), Hakimova E. (2013), Petrenko E. (2016), Vechkinzova E. (2016, 2017) and others.

In 2006, American urbanist Simon Evans introduced the concept of a creative cluster and defined it as "a community of creatively-oriented entrepreneurs who interact in a closed area" (Hakimova E., 2013). Sukhovskaya D. interprets the concept of "creative space" as a generally accessible territory intended for free expression, creative activity and interaction of people (Sukhovskaya D., 2013). The authors propose to consider creative spaces on the basis of the institutional approach, as a union on a certain territory of carriers of creative or intellectual innovation, capable of acquiring the form of a product (service) in a conditionally material form. We believe that the creation of creative space is a knot of the interaction of human capital, localized in those places where human communications and the state of the external environment form a synergy of creating products of joint creativity.

In the practice of state management of creative spaces in an urban environment, it is, first of all, providing residents with a creative environment rich in opportunities for aesthetic perception, training, involvement in creativity, with the exchange of skills, experimentation and the realization of their own humanistic vision. (Sukhovskaya D., 2013).

In a narrower sense, public administration considers the main purpose of the creative space as providing platforms for activities to representatives of creative professions. In a post-industrial society, the role of the creative class is increasing both in the degree of product creation and in the formation of aesthetic and social trends.

In Russia, the social influence of the creative class was, in our opinion, exaggeratedly represented in the media and received an oppositional political interpretation. The precedents for the participation of a number of representatives of creative professions in the protest movement distracted the attention of the public and the state from the creative role of creative work and slowed down the support of initiatives for the development of creative spaces on a national scale.

However, at present, creative spaces are no longer perceived in public policy as risk zones and their targeted, programmatic development is taking place.

Creative space can also serve as an office center, while having any non-standard features of the organization of work - for example, interior design, a higher number of recreational areas and territories of informal communication, or implying work in the open space format - such features, according to some researchers, help office employees overcome the routine nature of their work (Havierniková, K., Kordoš, M., 2019.). In addition to the economic function (offices and shops), creative spaces can also perform recreational and educational functions, serving as venues for various cultural events: exhibitions, lectures, film screenings. Functions can also be combined under one roof. The main types of creative spaces are coworking and art centers, art quarters, centers of modern art (Sukhovskaya D.N., 2015; Tkalenko, S., Zhulid-Khristosenko Yu., 2015; Žižka, M., Hovorková, V., Pelloneová, N., Štichhauerová, E., 2018; Bublienė, R., Vinogradova, I., Tvaronavičienė, M. Monni, S. 2019). Creative spaces are usually located in buildings that have lost their original purpose, but subsequently revitalized. Most often, these are former industrial buildings that receive a new function while maintaining their architectural appearance (Vechkinzova, E.A, Goridko, N.P., 2017).

The growth in the number of creative spaces is hindered by both a lack of finances for their organization and a low investment attractiveness. As a result, a creative space, if created, only serves as a temporary stage in the use of a particular territory, designed to increase interest in it, which may be followed by a new change in its 
functions (Petrenko, Y., Vechkinzova, E., Antonov, V., 2019). The main source of income for creative spaces is tenant payments, which is why poor cultural organizations cannot make up the majority of them. In addition, many creative spaces are located in former industrial buildings at a time when the cost of renting an unknown place is still low, but are forced to look for a new place with increasing payments (Lincaru, C., Pirciog, S., Grigorescu, A., Tudose, G., 2018.). Investors, as a rule, provide territories for creative spaces exactly until a more profitable application appears, which creates a potential conflict of interest between residents of the creative space and the owners of the territory (Amraoui, B., Ouhajjou, A., Monni, S., El Amrani El Idrissi, N., Tvaronavičienè, M., 2019).

Note that the creative potential of the artist, as well as the entrepreneur, is revealed only if there are special conditions that need to be formed, relying on a single marketing strategy. The terms "innovative development" and "requests of a post-industrial society" apply to the field of creative clusters.

Creative (creative) industries have recently been the object of study from the point of view of economic and cultural policy. There are quite a few definitions and classifications of creative (creative) industries, summarizing which, a set of criteria can be distinguished:

- the activities of such industries are closely related to culture or art (visual art, performing arts, literature, museums, galleries, cultural heritage);

- activities related to media production (press, publishing, television and radio broadcasting, digital media);

- design-related industries (architecture, industrial design, fashion, etc.).

\section{Research objective and methodology}

Numerous studies confirm that creative (creative) industries tend to clustering, that is, to unite into intersectoral complexes for further development. From the point of view of macroeconomics, clusters are "points of growth" and make it possible to fully realize the potential of the territory. For cluster participants, the advantage is the ability to use synergistic effects in order to get the most out of market advantages.

Creative clusters, creating the area of intersectoral cooperation, create conditions for the professional development of creative workers, increase the level of interactivity of cultural products created within the framework of creative clusters. Ultimately, such clusters contribute to more complete satisfaction of consumer demands in the creative services market.

The growth of the creative (creative) industries sector is associated with basic transformations in economic systems: the development of a post-industrial society and the formation of a knowledge-based economy, the growth of the services sector, and the increasing role of the creative class. The policy in relation to creative (creative) industries cannot be an extended version of the existing cultural policy based on the principles of the welfare economy, but should be considered as an element of innovation policy in the economy as a whole.

Both theorists and practitioners of "creative industries" agree that increasing their economic importance should change the cultural policies of countries and regions in favor of developing a cluster approach to the cultural sphere. And in this regard, the purpose of this study is to use the mathematical clustering method to identify both general trends in the formation of creative clusters in Kazakhstan and already formed clusters. The author of the theory of the creative class R. Florida (2002) proposed a creativity index, in which he included 3 groups of indicators: tolerance, talent, innovative technologies.

Given the above theory of R. Florida and the index proposed by him, the authors developed a method for identifying creative clusters in Kazakhstan based on the method of mathematical clustering. As factors of clustering, indicators of tolerance, talent and innovative technologies were identified. Based on the values of these indicators, the cities of Kazakhstan will be assigned to one or another cluster.

The difficulty in calculating the clusters was the fact that the state statistical agency of Kazakhstan does not 
collect all the necessary indicators that make up the Florida index, and a survey of experts brings a subjective position to the study. The authors formed 3 groups of synthetic (composite) indicators of tolerance, talent and technology only on the basis of available data from Kazakhstan statistics.

The synthetic indicator of tolerance for each city representing the center of administrative and regional division of Kazakhstan was calculated as the product of the indicator of variation of nationality and the indicator of the average weighted age of city residents.

The synthetic talent indicator for each region was calculated as the product of the normalized indicators of the number of employees performing research and development (the number of researchers) and the number of security documents issued.

The synthetic technology indicator for each region was calculated as the product of normalized indicators of the number of organizations that created and use new technologies and equipment objects and the number of new technologies and equipment objects created and used.

The calculation of mathematical clustering was carried out in the STATISTICA program.

\section{Results and discussion}

The values of the synthetic indicators of tolerance, talent and technology are calculated on the basis of statistical data of the Republic of Kazakhstan for each of the cities according to data for 2018 (Table 1).

Tab. 1. Calculation of synthetic indicators of tolerance, talent and technology

\begin{tabular}{|c|c|c|c|}
\hline & talent coefficient & tolerance coefficient & technology coefficient \\
\hline Aktau & 0,238 & 2,107 & 0,012 \\
\hline Aktobe & 0,051 & 1,94 & 22,705 \\
\hline Almaty & 43,997 & 1,487 & 3,213 \\
\hline Nur-Sultan & 4,178 & 1,972 & 0,475 \\
\hline Atyrau & 0,078 & 2,119 & 0,086 \\
\hline Karagandy & 1,029 & 1,204 & 0,198 \\
\hline Kokshetau & 0,207 & 1,17 & 0,853 \\
\hline Kostanay & 0,15 & 1,124 & 0,201 \\
\hline Kyzylorda & 0,026 & 2,174 & 0,342 \\
\hline Pavlodar & 0,234 & 1,249 & 0,785 \\
\hline Petropavlovsk & 0,009 & 1,132 & 0,462 \\
\hline Taldykorgan & 0,469 & 1,534 & 0,073 \\
\hline Taraz & 0,052 & 1,516 & 0,439 \\
\hline Oral & 2,354 & 1,701 & 0,007 \\
\hline Oskemen & 0,278 & 1,356 & 0,62 \\
\hline Shymkent & 0,574 & 1,566 & 22,705 \\
\hline maximum value & 43,997 & 2,174 & 0,007 \\
\hline minimum value & 0,009 & 1,124 & 1,922 \\
\hline average value & 3,370 & 1,584 & \\
\hline
\end{tabular}

Source: compiled by the authors

As can be seen from table 1, the lowest average value falls on the coefficient of tolerance - its maximum value is much lower than the minimum value of the talent coefficient and approximately equal to the minimum value of the technology coefficient. Such a low value of the coefficient of tolerance indicates a low national, age and cultural diversity of the population of the cities of Kazakhstan, which can become a serious obstacle to the for- 
mation of creative clusters and spaces in Kazakhstan. Indeed, the highest values of the coefficients of talent and technology correspond to the high value of the coefficient of tolerance. The only exceptions are cities located in the oil producing region (Kyzylorda, Oral, Aktau, Aktobe), where international oil developing and producing enterprises with a large staff of foreign employees are concentrated.

According to the logic of mathematical clustering, cities whose synthetic values are close will make up one common cluster. Using the Ward method and the Euclidean distance principle, the authors obtained the following distribution of regions (Fig. 1): Almaty, Uralsk, Nur-Sultan are separately distinguished at a confidence level of 4, and then a cluster that includes 2 groups from the remaining 13 cities of Kazakhstan.

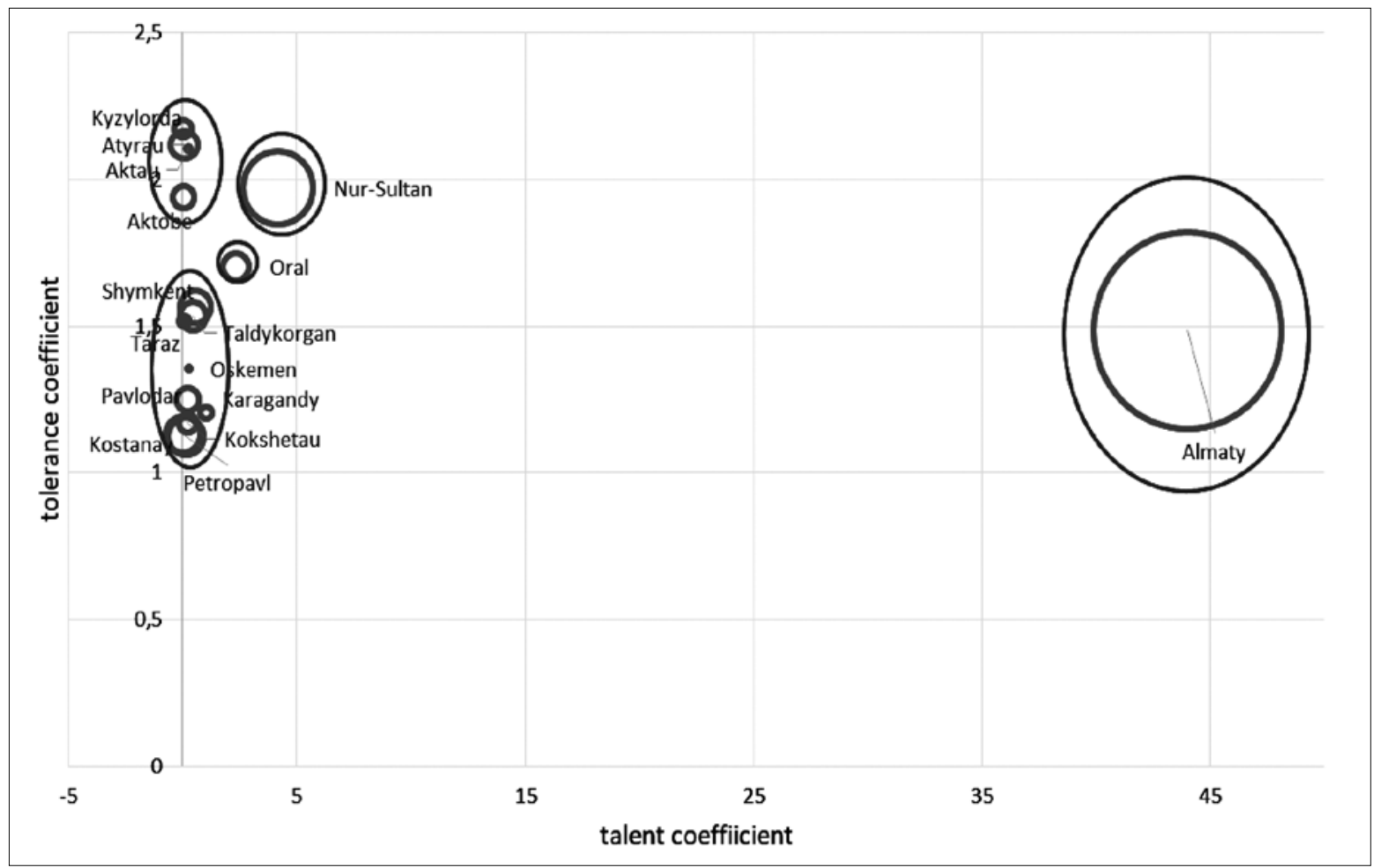

Figure 1. Clustering of the regions of Kazakhstan on the principle of Euclidean distance

Source: drawn by authors

At lower levels of trust, the Euclidean distance between cities also does not make it possible to visually highlight specific groups, while it is advisable to distribute all regions into 5 clusters.

Based on this, we applied the k-means method, as a result of which we obtained groups of regions that differ in the ratio of synthetic indicators of creativity (Table 2, Fig. 2).

Tab. 2. The average values of indicators for clusters

\begin{tabular}{|c|c|c|c|c|c|}
\hline & Cluster 1 & Cluster 2 & Cluster 3 & Cluster 4 & Cluster 5 \\
\hline tolerance coeffiicient & 1,48653 & 1,700539 & 1,316806 & 1,971984 & 2,084799 \\
\hline talent coefficient & 43,99709 & 2,353591 & 0,333582 & 4,177788 & 0,098334 \\
\hline technology coeffiicient & 22,70465 & 0,439227 & 0,380549 & 3,213292 & 0,241601 \\
\hline
\end{tabular}

Source: compiled by the authors based on the results of cluster analysis 


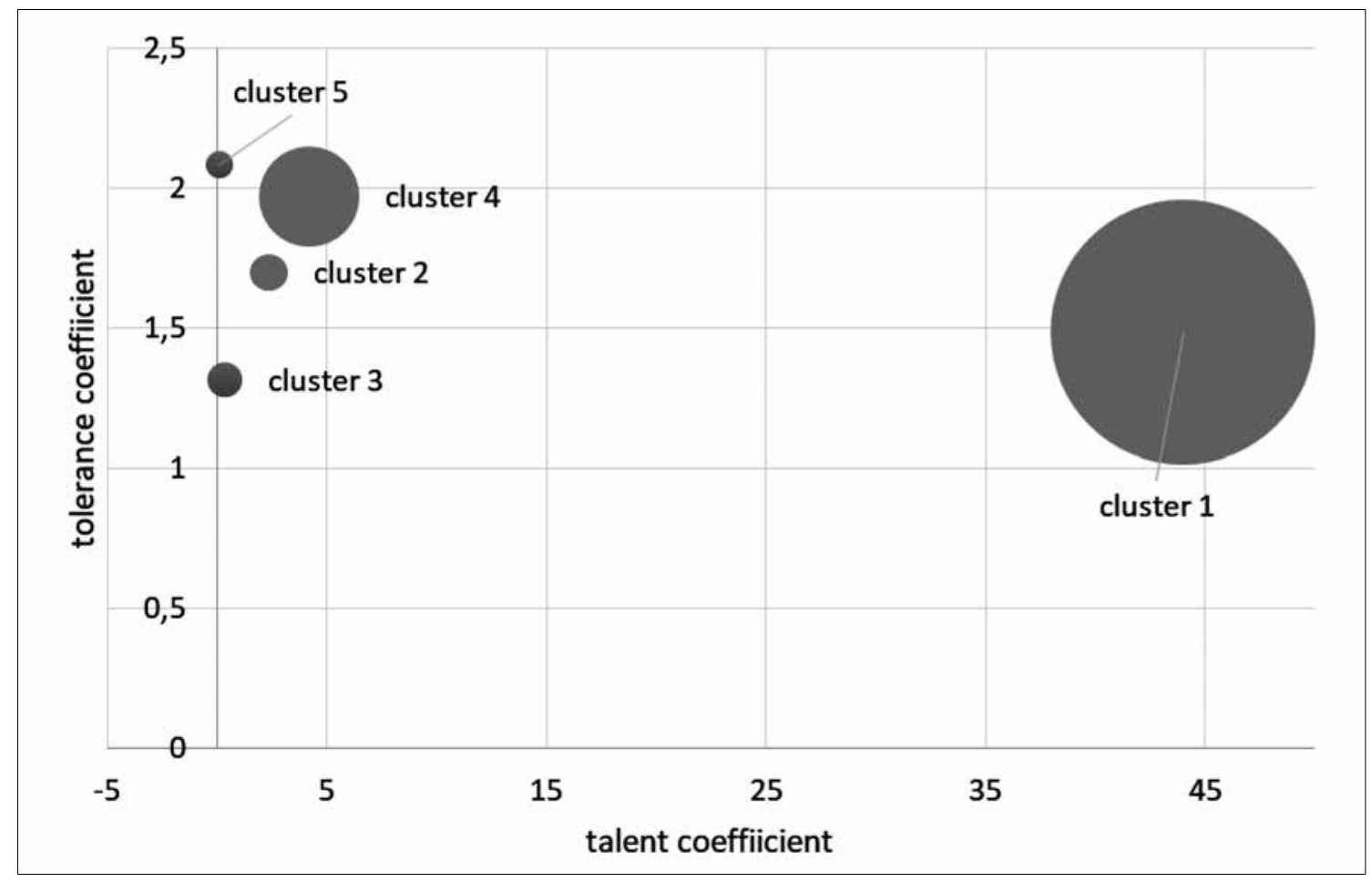

Fig. 2. Clustering of the regions of Kazakhstan using the k-means method

Source: drawn by authors

Consider the distribution of cities by cluster.

As a result of the mathematical clustering procedure, 3 cities were divided into separate clusters: cluster 1 - Almaty, cluster 2 - Uralsk and cluster 4 - Nur-Sultan.

Cluster 1, presented by Almaty, is characterized by the largest synthetic indicators of talent and technology with a fairly low indicator of tolerance. In a sense, Almaty is an exception, as The status of the former capital of Kazakhstan over the course of 50 years has allowed the formation of a high cultural, scientific environment and the attraction of sufficient financial resources to maintain a leading position in Kazakhstan for a long time in terms of talent and technology.

Cluster 2, represented by Uralsky, is characterized by an average synthetic indicator of tolerance and low indicators of talent and technology. The remoteness of the indicators of this city from other centers of the formed clusters is determined by the frontier location of the city and the active human, information and commodity exchange flows.

Cluster 4, represented by Nur-Sultan, is characterized by rather high indicators of talent and technology (in terms of indicators it is located immediately after the leader, Almaty) and a high indicator of tolerance.

Cluster 3 includes 9 cities, which are characterized by the lowest level of tolerance, and the level of talent and technology indicators is below average. Their list, as well as the distance from the center of the cluster are shown in table 3.

Cluster 3 is heterogeneous in composition: Pavlodar (0.073) is located closest to the center of the cluster, and Karaganda (0.441) is farthest from the center of the cluster. The distance of Karaganda to the center of cluster 3 exceeds twice the average value of the entire population of this cluster to its center, equal to 0.2425 . This situa- 
tion is due to the fact that Karaganda has a large scientific and technical potential accumulated in Soviet times, which unfortunately is not supported in recent years. According to the calculated data, it can be concluded that Karaganda tends to exit this cluster, or has recently joined it due to worsened trends in recent indicators. In addition to the extreme point of the cluster - Karaganda, one can also distinguish 2 more cities, with almost the same distance to the center of the cluster, also significantly remote from its center - Kostanay (0.313) and Petrapavlovsk (0.3176). This is due to the fact that both cities are bordering with Russia and more intensive cultural, scientific and technical exchange processes take place in them.

Tab. 3. Cities that make up cluster 3

\begin{tabular}{|c|c|}
\hline & Cluster center distance \\
\hline Karagandy & 0,441012 \\
\hline Kokshetau & 0,153641 \\
\hline Kostanay & 0,313083 \\
\hline Pavlodar & 0,073372 \\
\hline Petropavlovsk & 0,317633 \\
\hline Taldykorgan & 0,155173 \\
\hline Taraz & 0,266750 \\
\hline Oskemen & 0,219420 \\
\hline Shymkent & 0,242698 \\
\hline
\end{tabular}

Source: compiled by the authors based on the results of cluster analysis

Cluster 5 includes 4 cities representing the oil-producing western regions of Kazakhstan. It is characterized by the highest synthetic indicator of tolerance and the lowest indicators of talent and technology. Unlike cluster 3, the composition of cluster 5 is quite uniform: the minimum distance to the center of the cluster is at Kyzylorda (0.07) and the maximum is at Aktau (0.156). Which speaks of fairly homogeneous processes taking place in these cities.

Their list, as well as the distance from the center of the cluster are given in table 4 .

Tab. 4. Cities that make up cluster 5

\begin{tabular}{|c|c|}
\hline & Cluster center distance \\
\hline Aktau & 0,155649 \\
\hline Aktobe & 0,090677 \\
\hline Atyrau & 0,136472 \\
\hline Kyzylorda & 0,070437 \\
\hline
\end{tabular}

Source: compiled by the authors based on the results of cluster analysis

General characteristics of cities with shaped creative spaces are presented in table 5.

Tab. 5. General characteristics of the formed creative clusters

\begin{tabular}{|c|c|c|c|c|c|c|}
\hline & $\begin{array}{c}\text { tolerance } \\
\text { coefficient }\end{array}$ & $\begin{array}{c}\text { talent } \\
\text { coefficient }\end{array}$ & $\begin{array}{c}\text { technology } \\
\text { coefficient }\end{array}$ & $\begin{array}{c}\text { average values of } \\
\text { the coefficients }\end{array}$ & cluster characteristic & tendencies \\
\hline Almaty & 1,487 & 43,997 & 22,705 & 22,73 & $\begin{array}{c}\text { independent cluster } 1 \text { (distance to the } \\
\text { center 0 - is the center of the cluster) }\end{array}$ & formed \\
\hline Nur-Sultan & 1,972 & 4,178 & 3,213 & 3,12 & $\begin{array}{c}\text { independent cluster } 4 \text { (distance to the } \\
\text { center 0 - is the center of the cluster) }\end{array}$ & formed \\
\hline Oral & 1,701 & 2,354 & 0,439 & 1,49 & $\begin{array}{c}\text { independent cluster } 2 \text { (distance to the } \\
\text { center 0 - is the center of the cluster) }\end{array}$ & formed \\
\hline
\end{tabular}

Source: compiled by the authors based on the results of cluster analysis 
As can be seen from the calculations, in three cities their creative spaces were actually formed - Almaty, NurSultan and Uralsk in the calculations were separated into separate clusters and have the highest average values of three coefficients (tolerance, talent and technology).

The position of the city of Karaganda, which is part of group cluster 3 (the distance to the center is 0.441 , is also interesting. The city is located on the outer border of the cluster, farthest from all cities from the center of the cluster. This situation indicates that Karaganda is very different in its indicators from the rest representatives of the cluster, and in previous periods of time the city was not part of this cluster. Indeed, if we carry out calculations for the previous 3 years, we will see that the potential for creating creative space in Karaganda is lost tsya - in connection with the fall of the last 3 years the coefficient values, the city of self-cluster passed the cluster 3.

Thus, from 16 cities of Kazakhstan, which are the centers of the regions, only in 3 cities can one observe the formed creative clusters. It is significant that 2 cities (Almaty and Nur-Sultan) are the former and current capitals of Kazakhstan, which are centers of economic, cultural and scientific life, having diplomatic missions and cultural centers of many states within urban areas. And Uralsk is the regional center of the oil industry in Kazakhstan and is also a border region with intensive cross-border processes of economic and cultural exchange.

A decrease in the tolerance coefficient leads not only to a risk of low susceptibility of cultural indigents from other countries, but also to a decrease in the variety of forms and ways of thinking, creative realization, selfexpression, which directly affects the country's innovative and economic development.

\section{Conclusions}

Based on the study, the following conclusions can be drawn:

Firstly, creative spaces attract a creative class that does not have strict characteristics by occupation and income, which makes it a place for all kinds of people to unite by age, gender, profession, marital status, etc.

Secondly, such spaces are the cultural center of the city, conducting exhibitions, film screenings, concerts and much more on its territory.

Thirdly, creative spaces are multifunctional, because allow to carry out both cultural and educational events on their sites. It also houses establishments of various kinds - cafes, bars, shops, offices, coworking, etc.

Fourth, creative spaces often reuse abandoned or historic buildings, thus helping to intelligently utilize vacant territories and improve the look of the city by restoring these buildings.

Fifth, creative spaces provide their space for associations of small and medium-sized businesses, which favorably affects the development of these initiatives.

Sixth, a decrease in tolerance directly reduces the potential for the formation of creative spaces, and is also an indicator of the risk of monocultural development, Kazakhstan's lag in the educational, scientific and innovative spheres of the international country community.

\section{References}

Amraoui, B., Ouhajjou, A., Monni, S., El Amrani El Idrissi, N., Tvaronavičienè, M. 2019. Performance of clusters in Morocco in the shifting economic and industrial reforms, Insights into Regional Development, 1(3): 227-243. https://doi.org/10.9770/ird.2019.1.3(4)

Bublienè, R., Vinogradova, I., Tvaronavičienè, M. Monni, S. 2019. Legal form determination for the development of clusters` activities. Insights into Regional Development, 1(3), 244-258. https://doi.org/10.9770/ird.2019.1.3(5)

Florida, R. 2002. The Rise of the Creative Class: And How It's Transforming Work, Leisure, Community and Everyday Life. New York: 
Basic Books, 404 p. ISBN 0465024777.

Hakimova, E.R. 2013. Creative cluster as an element of the creative potential of the territory. Actual problems of economic sciences. No. 34: 121 - 124. https://elibrary.ru/item.asp?id=20722326

Havierniková, K., Kordoš, M. 2019. Selected risks perceived by SMEs related to sustainable entrepreneurship in case of engagement into cluster cooperation. Entrepreneurship and Sustainability Issues, 6(4): 1680-1693. http://doi.org/10.9770/jesi.2019.6.4(9)

Hhakimova, E.R. 2013. Creative cluster in the concept of an innovation system. Theory and practice of social development, 2: 236 238/ https://elibrary.ru/item.asp?id=18793974

Hoyman, M. and Faricy, C. 2009. It Takes a Village: A Test of the Creative Class, Social Capital and Human Capital Theories (December 9, 2008). Urban Affairs Review, January 2009. Available at SSRN: https://ssrn.com/abstract=1313563

Landry, Ch. 2008. The Creative City: A Toolkit for Urban Innovators 2nd Edition, 352 p. ISBN-13: 978-1844075980, ISBN10: 1844075982

Lincaru, C., Pirciog, S., Grigorescu, A., Tudose, G. 2018. Low-Low (LL) High Human Capital Clusters In Public Administration Employment - Predictor for Digital Infrastructure Public Investment Priority - Romania Case Study. Entrepreneurship and Sustainability Issues, 6(2): 729-753. http://doi.org/10.9770/jesi.2018.6.2(18)

Markusen, A. 2006. Urban development and the politics of the creative class: Evidence from the study of artists. Environment and Planning A: Economy and Space, 38 (10): 1921-1940. https://doi.org/10.1068/a38179

Montgomery, J. 2005. Beware 'the Creative Class'. Creativity and Wealth Creation Revisited. Local Economy, 20(4): 337-343. https:// doi.org/10.1080/02690940500298706

Petrenko, Y., Vechkinzova, E., Antonov, V. 2019. Transition from the industrial clusters to the smart specialization of the regions in Kazakhstan. Insights into Regional Development, 1(2): 118-128. https://doi.org/10.9770/ird.2019.1.2(3)

Rindermann, H. and Thompson J. 2011. Cognitive capitalism: The effect of cognitive ability on wealth, as mediated through scientific achievement and economic freedom. Psychological Science 22 (6): 754-763. https://doi.org/10.1177/0956797611407207

Rindermann, H., Sailer, M. and Thompson, J., 2009. The impact of smart fractions, cognitive ability of politicians and average competence of peoples on social development. Talent Development and Excellence 1(1): 3-25. http://k12accountability.org/resources/GiftedEducation/Impact_of_Smart_Fractions.pdf

Sukhovskaya, D.N. 2013. Realization of the creative potential of the population through the creative spaces of the city: lofts, coworking zones, art territories. Young scientist 10: 650-652. https://moluch.ru/archive/57/7762/

Sukhovskaya, D.N. 2015. Creative space of Russian urban settlements and its impact on the formation of value orientations of the individual. The dissertation for the degree of candidate of philosophical sciences, specialty 09.00.11 - Social Philosophy. Krasnodar, Krasnodar University of the Ministry of Internal Affairs of the Russian Federation, 198 p. https://elibrary.ru/item.asp?id=28852991

Tkalenko, S., Zhulid-Khristosenko Yu. 2015. Clustering of creative industries of the European Union. Problems and Prospects of Economics and Management 4(4): 86 - 92. https://elibrary.ru/item.asp?id=27207869

Vechkinzova, E.A, Goridko, N.P. 2017. Clustering of the regions of Kazakhstan: the role of innovation and investment. Materials of the IV All-Russian Symposium on Regional Economics. Ekaterinburg: Institute of Economics, Ural Branch of the Russian Academy of Sciences: 83-87. ISBN 978-5-94-646-589-2. https://elibrary.ru/item.asp?id=30355582

Vechkinzova, E.A., Petrenko, Ye.S. 2016. From clusters to smart specialization: a review of methodological approaches. Proceedings of the VII All-Russian Symposium on Economic Theory. Volume 2. Yekaterinburg: Institute of Economics, Ural Branch of the Russian Academy of Sciences: 56 - 58. ISBN: 978-5-94646-547-2 https://elibrary.ru/item.asp?id=26305499

Žižka, M., Hovorková, V., Pelloneová, N., Štichhauerová, E. 2018. The effect of clusters on the innovation performance of enterprises: traditional vs new industries, Entrepreneurship and Sustainability Issues 5(4): 780-794. http://doi.org/10.9770/jesi.2018.5.4(6) 
JOURNAL OF SECURITY AND SUSTAINABILITY ISSUES

ISSN 2029-7017 print/ISSN 2029-7025 online

Yelena PETRENKO

ORCHID ID: orcid.org/0000-0001-6892-2392

\section{Elena VECHKINZOVA}

ORCID ID: orcid.org/0000-0003-2543-625X

\section{Lyussiya TOGAIBAYEVA}

ORCHID ID: orcid.org/0000-0002-4469-5022

This work is licensed under the Creative Commons Attribution International License (CC BY).

http://creativecommons.org/licenses/by/4.0/ 